\title{
Urinary Porphyrin Profile as Early Biomarker vis-a-vis Malonaldehyde as Oxidative Stress Indicator in Arsenic Exposed Individuals, West Bengal, India
}

\author{
Ashit K. Mukherjee *, ${ }^{\text {, }, ~ S u j o y ~ K . ~ M a n n a ~}{ }^{1}$, Sanjit K. Roy ${ }^{1}$, Jnan P. Naskar ${ }^{2}$ \\ ${ }^{1}$ Regional Occupational Health Centre (Eastern), (Indian Council of Medical Research) Salt Lake, Kolkata- \\ 700091, India \\ ${ }^{2}$ Department of Chemistry, Inorganic Chemistry Section, Jadavpur University, Kolkata-700 032, India \\ *Corresponding Author: Dr. Ashit Kumar Mukherjee, Regional Occupational Health Centre (Eastern), \\ (Indian Council of Medical Research) SaltLake, Kolkata-700091, India. Email: \\ ashit_mukherjee@yahoo.com
}

\begin{abstract}
Exposure to arsenic contaminated ground water has been a global environmental health hazard for 2/3 decades. Multi-organ diseases including cancers have been reported in humans chronically exposed to arsenic. Urinary porphyrin profiles and MDA induced by arsenic may be useful for prevention of health risk in endemic areas. Study measured ground water arsenic and urine arsenic among adult individuals from control and exposed areas of West Bengal, India respectively by flow injection atomic spectroscopy and transversely-heated graphite atomiser techniques. Porphyrins, uroporphyrin III, heptacarboxyporphyrin I, hexacarboxyporphyrin I, pentacarboxyporphyrin I, coproporphyrin III and malonaldehyde in urine of control and exposed individuals were analysed separately by HPLC using fluorescence detector. Significant statistical association between water and urine arsenic was noticed among population exposed to, $<50 \mu g$ As/L and > 50 $\mathrm{g}$ As/L water. Higher levels of uro III, hepta I and Copro III, were observed in group exposed to $>50 \mu \mathrm{g}$ As/L water, irrespective of gender and age. Higher porphyrins in group exposed to, <50 $\mu \mathrm{g} A \mathrm{~s} / \mathrm{L}$ water compared to control indicate, change in porphyrin profile starts before appearance of skin changes. Ratio, copro III/ uroIII, also increased significantly with exposure and age. A good correlation was observed in the regression analysis between U-As against uro III and copro III for exposed population. Oxidative stress condition was revealed by elevated MDA with increased $U$-As. Study demonstrated a positive correlation between $U$-As and porphyrins in exposed and control individuals indicating bio-chemical toxicity. Exposed individuals with raised MDA indicated oxidative cellular damage to confirm oxidative stress. Altered porphyrin profiles even in younger group suggest it to be potential early biomarker.
\end{abstract}

Abbreviations: uro III, Uro porphyrin III dihydrochloride; hepta I, Heptacarboxy porphyrin I heptamethyl ester; hexa I, Hexacarboxy porphyrin I hexamethyl ester; penta I, Pentacarboxy porphyrin I pentamethyl ester; copro III, Copro porphyrin III tetramethyl ester; MDA, Malonaldehyde; TEP, 1, 1, 3, 3-tetra ethoxy propane; TBA, 2-thio barbituric acid; U-As, Urine arsenic; W-As, Water arsenic; FIAS-AAS, Flow injection atomic spectroscopy; THGA-AAS, transversely-heated graphite atomiser

Keywords: Water arsenic, Urine arsenic, Porphyrins, Malonaldehyde, Biomarker, Oxidative stress.

\section{INTRODUCTION}

The adverse health effects caused by chronic arsenic exposure of natural origin have been a major global health concern. A large number of people (approx. 150 million) have been suffering from various arsenic related diseases all over the world [1]. Prolonged chronic exposure to arsenic causes multi-organ diseases like skin lesions (melanosis, keratosis and Bowen's disease), gastrointestinal diseases, cardiovascular and respiratory diseases, and neurological, haematological and hepatic disorders, diseases of kidney, liver, and cancers, mainly of skin, lung and urinary bladder [2 - 6]. More than 6 million people in West Bengal, India are exposed to arsenic contaminated drinking water (above the National permissible limit of $50 \mu \mathrm{g} / \mathrm{L})$. Alarmingly, an estimated population of more than 0.3 million has been reported to have skin lesions [7]. Skin lesions have been considered as a long-term biomarker of cumulative arsenic exposure and as a major diagnostic criterion in screening the affected population [8]. The typical arsenical skin 
manifestations generally take place after 5 to 10 years' exposure. Therefore, to diagnose a case, sufficient time is required to get a visible and hence detectable symptom. Urinary total arsenic is often considered as a biomarker of current exposure, but once the exposure is stopped, arsenic (both inorganic and organic forms) ceases to excrete through urine within 4-5 days [9]. As a result, individual value of urine arsenic is not always reflected according to its proportional exposure value. Inorganic arsenic has been classified as a group 1 and group $\mathrm{A}$ carcinogen to mankind by the International Agency for Research on Cancer (IARC), 1987 and the U.S. EPA, 1993 respectively, based on anthropogenic evidence [10, 11]. It has been evidenced that the latency to develop arsenic related cancers in humans needs decades of exposure to arsenic, $>50 \mu \mathrm{g} / \mathrm{L}$ water. This latency prevails even after the exposure ceases [12]. Thus, a suitable and reliable early biomarker of chronic arsenic exposure is of utmost demand to take remedial measures for the affected people before hand.

Heme, a macrocyclic iron-containing molecule, is synthesized mostly in bone marrow (85\%) and liver $(15 \%)$ for the synthesis of hemoglobin in bone marrow and hemoproteins in the liver $[13,14]$. The heme biosynthetic pathway plays an important role in all nucleated cells to provide heme and related compounds that involve eight enzymes in a sequence. Porphyrinogens are produced as intermediates in the biosynthetic pathway of heme $[15,16]$. It is also reported that chronic exposure to environmental heavy metals (e.g. As, $\mathrm{Hg}, \mathrm{Pb}$ ) may bind to the enzyme to affect the metabolism that alter the urinary porphyrin profile $[17,18]$. Chronic exposure to arsenic $\left(\mathrm{As}^{+3}\right.$ and $\left.\mathrm{As}^{+5}\right)$ lead to accumulate in different target organs and exert its deleterious effects on the heme-metabolism in humans and accumulate porphyrins, the oxidized by-products which lower hemoglobin level [19]. In the arsenic exposed area, intermediates of heme biosynthetic pathway come into urine in appreciable amount due to arsenic exposure than the unexposed. The specific porphyrin intermediates may serve as an early biomarker of chronic arsenic toxicity [20 - 23]. The ratios of key intermediates may also help to identify the toxicant and also to indicate accumulation of abnormal intermediates in the pathway. Only a few of these intermediates may be the potential biomarker of arsenic exposure. Though porphyrin intermediates in the urine of arsenic exposed population have been studied, no definite intermediate in porphyrin profile has yet been established as a biomarker of arsenic exposure. Therefore, assessment of specific porphyrins in the heme forming pathway may be a useful parameter to identify it as the early biomarker of arsenic toxicity. Again, it may be useful to screen the affected people well in advance.

It has been reported that chronic exposure to inorganic arsenic on long term basis leads to generate reactive oxygen species (ROS) which induces oxidative stress [24, 25]. Among the many targets of oxidative stress, lipids are the most involved class of biomolecules which produce a number of secondary products on oxidation. MDA, a highly reactive and toxic compound, has been studied widely as an indicator of oxidative stress and lipid peroxidation. The potentiality of lipid peroxidation can be estimated by the amount of MDA present in the tissues [26 - 29]. Studies revealed that ROS, responsible for vascular injury, induces increased risk of cancers, including cancers of skin, bladder, lung and liver among exposed population [30]. MDA status has been suggested as a good bioindicator of arsenic toxicity as well as a biomarker of oxidative stress [31].

A few studies were published on the urinary porphyrin profile and urinary MDA level due to chronic arsenic exposure through drinking water in arsenic endemic area as well as due to arsenic emitted from burning of contaminated coal in China [32]. Reports are also available only on urinary porphyrins as biomarkers of chronic arsenic toxicity due to contaminated drinking water from Mexico, burning of coal from China and smelting of gold-arsenic ore from SouthWest France [33 - 36]. Urinary arsenic, MDA and prevalence of arsenicosis were also studied in arsenic endemic area Guizhou province, China to observe the oxidative stress condition among exposed population [31].

The present cross-sectional study undertaken in 2012-13, highlights the urinary porphyrin profiles as a biomarker of toxic effects among the exposed population in arsenic endemic area of West Bengal in India. The altered porphyrin profile caused by the toxic insult through contaminated drinking water may affect the heme metabolism and the intermediates formed will serve as early warning biomarker for 
chronic exposure to arsenic. Besides, this study measures the urinary MDA to find out the prevailing condition of oxidative stress among the exposed population in the endemic area where no such report is hitherto available. Thus, the study will focus on the non-carcinogenic and carcinogenic risk among the humans chronically exposed to arsenic through drinking water.

\section{MATERIALS AND METHODS}

\subsection{Reagents And Standards}

The individual chromatographic standards, Uroporphyrin III dihydrochloride (uro III), Heptacarboxyporphyrin I heptamethyl ester (hepta I), Hexacarboxyporphyrin I hexamethyl ester (hexa I), Pentacarboxyporphyrin I pentamethyl ester (penta I) and Coproporphyrin III tetramethyl ester (copro III), Mesoporphyrin IX dimethyl ester were purchased from Porphyrin products (Logan, Utah, USA) for the estimation of porphyrins. Standards of 1, 1, 3, 3tetra ethoxy propane (TEP), 2-thio barbituric acid (TBA) were obtained from Sigma-Aldrich, India for estimation of MDA. HPLC grade, potassium dihydrogen phosphate, phosphoric acid, potassium hydroxide, glacial acetic acid were procured from Spectrochem, India for preparation of mobile phase and HPLC grade acetonitrile, ammonium acetate and methanol were bought from Merck, India for preparation of solvents. Arsenic standard (Sigma Aldrich), Suprapur grade Sodium borohydride (Sigma Aldrich), Suprapur grade hydrochloric (Merck, Germany) and Suprapur grade nitric acids (Merck, Germany) were procured for the estimation of arsenic by AAS. Creatinine standard was purchased from Merck, India. HPLC grade water was used throughout the analysis.

\subsection{Study Subjects}

The study was conducted in two villages, selected on the basis of preliminary pilot health survey. One village affected by ground water arsenic and the other, having no report of ground water arsenic contamination called unexposed (control) village in N-24 Parganas district of West Bengal, India. The study involved a randomly selected adult population, 33 (6 female, having age range, 27-57 years and 27 male, having age range, 26-64 years) from control village with no case of arsenicosis and 62 (29 females, having age range, $27-65$ years and 33 males, having age range, $18-77$ years) from exposed village having reported cases of arsenicosis. The detailed history of water consumption was collected from the recruited subjects in a pre-designed pro-forma by visiting door to door. Written signed consent from each participant (male and female) was taken before recruitment and as per the norms of Institutional Ethics Committee (IEC) of Regional Occupational Health Centre (Eastern), Kolkata under Indian Council of Medical Research (ICMR). The confidentiality of the personal data was maintained. The majority of the subjects in both the villages were occupationally rickshaw pullers, daily labourers and small business owners who were engaged in the surrounding area. Most of the subjects were illiterate and belong to economically poor families. The exclusion criteria for selection of subjects were alcoholics and those having major disease (liver disease), pregnancy not directly related to arsenic exposure.

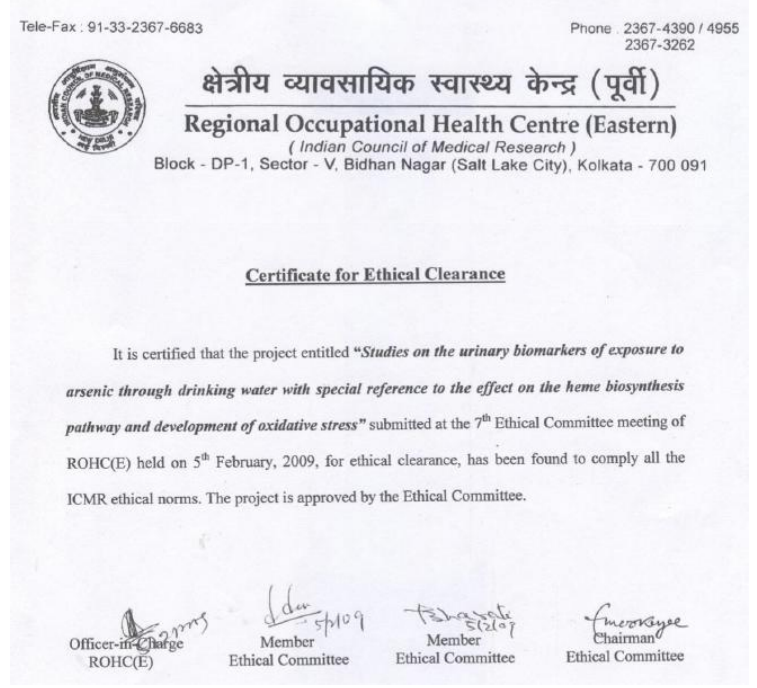

\subsection{Environmental Monitoring}

Collection of drinking water samples: Tube wells water samples, 25 Nos. from unexposed area and 45 Nos. from exposed area were collected in pre-washed polythene bottles and preserved in deep fridge at $-20{ }^{\circ} \mathrm{C}$ until analysed as per standard method.

Arsenic estimation in drinking water: Water samples were analysed for arsenic by using the AAS-FIAS (Perkin Elmer-AA-800) at the absorbance wavelength $193.7 \mathrm{~nm}$ [37, 38].

\subsection{Biological Monitoring}

Monitoring of arsenic in urine along with estimation of urinary porphyrins and MDA were undertaken from the subjects of control and exposed areas respectively. 
Collection of urine samples: One time spot urine samples were collected during morning hours (not the first void) from the subjects of both exposed and control area in $30 \mathrm{~mL}$ pre-washed polyethylene containers added with $1 \% \mathrm{HCl}$ as preservative and were stored at $-20^{\circ} \mathrm{C}$ till analysis (within a week).

\subsection{Estimation of urinary Porphyrins}

Urinary porphyrins were estimated by reverse phase HPLC, Model SCL-10 AVP system, Shimadju, Japan, having binary gradient pump (LC-10 AT vp), Rheodyne manual injector and a RF Xenon fluoresence lamp as detector [35].

\subsubsection{Selection of Column}

A reverse phase $\mathrm{C}_{18}$, HPLC column (Radialpak, Novapak), 8 X $100 \mathrm{~mm}, 4 \mu \mathrm{m}$ with a Novapak guard column, Water Associates, USA was used for separation of urinary porphyrins.

\subsubsection{Selection of mobile phase}

Two mobile phases were used for separation of porphyrins. Mobile phase A consisted of a mixture of anhydrous ammonium acetate, acetonitrile in HPLC grade water. The $\mathrm{pH}$ of the solution was adjusted to 5.16 with glacial acetic acid. The employed mobile phase B was $10 \%$ acetonitrile in methanol. The programme adopted for the separation of porphyrins was as per the method followed earlier by Wang et al [35].

\subsubsection{Preparation of standards}

Stock solutions for each of the porphyrins, uro III, hepta I, hexa I, penta I and copro III of concentration, $1 \mu \mathrm{mol} / \mathrm{L}$ were prepared separately in $1 \mathrm{~mL}$ of $3 \mathrm{~mol} / \mathrm{L} \mathrm{HCl}$ and $9 \mathrm{~mL}$ of $1 \mathrm{~mol} / \mathrm{L} \mathrm{HCl}$. Stock solution of $1 \mu \mathrm{mol} / \mathrm{L}$ for the Internal Standard (I.S) was also prepared similarly. Working standards were prepared from the above stock solution with $0.1 \mathrm{~mol} / \mathrm{L}$ $\mathrm{HCl}$. Concentration of porphyrins in working standards were 1.0, 2.0, 5.0, 10.0, 20.0, 50.0, 75.0 and $100.0 \mathrm{nmol} / \mathrm{L}$. All the stock of standard and I.S were stored at $-20{ }^{\circ} \mathrm{C}$.

\subsubsection{Calibration and linearity}

An eight point calibration curve was prepared for porphyrins and the average of the 3 injections was taken. Satisfactory linearity was observed with correlation coefficients ranging between 0.991 to 0.998. Limit of Detection (LOD) was assessed in presence of I.S by the ratio of the peak height to that of a noise as 3:1 and the repeatability was checked by three consecutive measurements within the same day. We have added mesoporphyrin in such a way that it had concentration in the standard mixture or sample of $100 \mathrm{nmol} / \mathrm{L}$.

\subsubsection{Recovery}

The percentage recovery of porphyrins was determined by comparing the ratios of the peak areas of the chromatograms of porphyrins of unexposed, spiked with three different standard mixtures of porphyrins and I.S to that of the unspiked sample along with I.S.

\subsubsection{Sample preparation}

The sample preparation was performed as per the following the published procedure by Wang et al.[35]. The stored samples were thawed to room temperature. At the first step, a mixture comprising $750 \mu \mathrm{L}$ of urine and $50 \mu \mathrm{L}$ of concentrated $\mathrm{HCl}$ was taken in an eppendorf tube. It was then vortex-mixed and was allowed to stand for almost $1 \mathrm{hr}$ in dark at room temperature to precipitate protein and also to convert porphyrinogen to porphyrin. Then it was centrifuged at $10,000 \mathrm{r} / \mathrm{min}$ for $10 \mathrm{~min}$. The concentration of I.S in the sample mixture was kept at $100 \mathrm{nmol} / \mathrm{L}$ in the final solution. The chromatogram of the porphyrins, uro P III, hepta I, hexa I and penta I, copro III and mesoporphyrine as internal standard (I.S) in urine of arsenic exposed population of $\mathrm{N}-24$ Parganas district, West Bengal, India is shown in Figure 1.The retention time, linearity, LOD, correlation coefficients and percentage recovery of porphyrins in humans urine in the presence of internal standard are tabulated below:

\begin{tabular}{|l|l|l|l|l|l|}
\hline Parameters & uro & hepta I & hexa I & penta I & $\begin{array}{c}\text { copro } \\
\text { III }\end{array}$ \\
\hline $\begin{array}{l}\text { Retention } \\
\text { time (min) }\end{array}$ & 4.8 & 5.8 & 6.8 & 7.9 & 9.3 \\
\hline $\begin{array}{l}\text { Linear } \\
\text { range } \\
\text { (nmol/L) }\end{array}$ & $1-100$ & $1-100$ & $1-100$ & $1-100$ & $1-100$ \\
\hline $\begin{array}{l}\text { LOD } \\
\text { (nmol/L) }\end{array}$ & 0.5 & 0.5 & 1 & 0.5 & 0.5 \\
\hline $\begin{array}{l}\text { Correlation } \\
\text { coefficient }\end{array}$ & 0.996 & 0.991 & 0.995 & 0.998 & 0.998 \\
\hline $\begin{array}{l}\text { Recovery } \\
\text { \%) }\end{array}$ & 96.1 & 105.4 & 91.8 & 91.7 & 103.9 \\
\hline
\end{tabular}




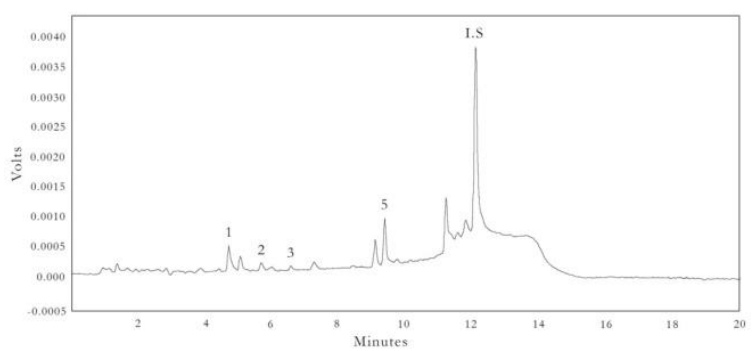

Figure1. Chromatogram of porphyrins, uro III, hepta I, hexa I and penta I, copro III and mesoporphyrine as internal standard (I.S) in urine of arsenic exposed population of N-24 Parganas district, West Bengal, India. [Peak No.1= uro P III; Peak No.2 =hepta I; Peak No.3= hexa I; Peak No.4=penta I; Peak No.5 =copro III and Internal standard (I.S)].

\subsection{Estimation of MDA in Urine}

The MDA level was estimated by HPLC method using the same make and model of the instrument as above with the fluorescence detector at excitation and emission wavelengths of 532 and $553 \mathrm{~nm}$ respectively [39].

\subsubsection{Selection Of Column}

Separation of the MDA was achieved with an analytical HPLC column, Luna $\mathrm{C}_{18}$ (2) (150 x $4.6 \mathrm{~mm}, 5 \mu \mathrm{m})$, coupled with a guard precolumn, procured from Phenomenex USA. The HPLC analysis was performed at an oven temperature of $30^{\circ} \mathrm{C}$.

\subsubsection{Selection Of Mobile Phase}

The mobile phases used for HPLC consisted of, A: $0.05 \mathrm{~mol} / \mathrm{L}$ potassium dihydrogen phosphate $(\mathrm{pH}=6.8)$ and $\mathrm{B}$ : methanol $(58 / 42)$. The mobile phase and water, used during analysis, were degassed by passing through $47 \mathrm{~mm}, 0.2 \mu \mathrm{m}$, hydrophilic polypropylene membrane filters (Pall Corporation) prior to its use. The chromatographic separation of the MDA was performed using isocratic programme for $5 \mathrm{~min}$. at a constant flow rate of $0.8 \mathrm{~mL} / \mathrm{min}$. The retention time of MDA was approximately 2.4 min.

\subsubsection{Preparation of Standards for MDA in urine}

Estimation of MDA was based on the reaction of TEP with TBA. Stoichiometric amount of MDA was generated under a hot acidic condition. A stock standard solution of 10 $\mathrm{mmol} / \mathrm{L}$ MDA was prepared by mixing 123.5 $\mu \mathrm{L}$ of TEP in $50 \mathrm{~mL}$ ethanol $(40 \%$ ethanol by volume).

\subsubsection{Calibration and linearity}

The working standards, in the range of 0.5-10 $\mu \mathrm{mol} / \mathrm{L}$ were prepared every day. Seven-point calibration curve was drawn with the standards having the concentrations $0.5,1.0,2.0,4.0,5.0$, 7.5 and $10.0 \mu \mathrm{mol} / \mathrm{L}$. All solutions were stored under refrigeration. The correlation co-efficient of the calibration curve was found to be 0.997 .

\subsubsection{Sample Preparation}

MDA in urine was measured following the method reported earlier [39]. Sample was prepared by mixing $300 \mu \mathrm{L}$ of phosphoric acid $(0.5 \mathrm{~mol} / \mathrm{L})$ with $50 \mu \mathrm{L}$ of urine and $150 \mu \mathrm{L}$ of TBA reagent $(23 \mathrm{mmol} / \mathrm{L})$ The mixture was incubated at $95^{\circ} \mathrm{C}$ for $1 \mathrm{hr}$ and then $500 \mu \mathrm{L}$ of methanol was added to each tube. The samples were centrifuged for $5 \mathrm{~min}$. at $5000 \mathrm{~g}$, filtered through Swinney syringe with a $0.22 \mu \mathrm{m}$ Millipore filter paper. Then an aliquot of $20 \mu \mathrm{L}$ of the reaction mixture was directly injected into the HPLC system. The chromatogram of MDA in urine of arsenic exposed population of N-24 Parganas district, West Bengal, India is shown in Figure 2. The LOD, linearity and correlation coefficients of MDA were respectively found to be $0.05 \mu \mathrm{mol} / \mathrm{L}, 0.5-10 \mu \mathrm{mol} / \mathrm{L}$ and 0.997 .

\subsubsection{Estimation of Arsenic in Urine}

The urine samples were digested in microwave digestion system (Ethos D, Milestone, USA) using nitric acid. Urine arsenic (U-As) was estimated as arsenate using THGA technique, using AA-800 attached with Graphite Furnace, Perkin Elmer [40].

\subsubsection{Measurement of Creatinine}

Urine creatinine was determined by the standard Jaffe method [41].

\subsection{Statistical Analysis}

SPSS statistical software (Version 17) was used for the data analysis of the study. Student t-test was applied for the statistical comparison of concentrations of urinary creatinine, porphyrins and MDA for significant tests between male and female and also for control versus exposed population. A correlation study was observed between urine arsenic versus water arsenic, urine arsenic versus urine porphyrin levels and also between urine arsenic versus urine malonaldehyde levels. 


\section{RESULTS AND DISCUSSION}

Table 1 shows the arsenic content in urine $(\mu \mathrm{g} / \mathrm{g}$ creatinine) according to arsenic exposure range of the control and exposed area population in arsenic endemic area of West Bengal. There was a significant difference $(P<0.0001)$ in urine arsenic between male who had exposed to, WAs, $<50 \mu \mathrm{g} / \mathrm{L}$ of exposed area and the male of control area. Significant difference $(P<0.0001)$ was also noticed between exposed male, who had exposed to, W-As $>50 \mu \mathrm{g} / \mathrm{L}$, and that of the control as well as between total exposed and control male. Significant differences were also observed for urinary arsenic between the control and exposed female population, who had exposed to, W-As, $<50 \mu \mathrm{g} / \mathrm{L}(P<0.001),>50$ $\mu \mathrm{g} / \mathrm{L}(P<0.001)$ and total exposed $(P<0.05)$ respectively. When we compared the values of urinary arsenic, combined together (i.e., male and female), significant differences were noticed between control and exposed, who had exposed to, W-As $<50 \mu \mathrm{g} / \mathrm{L}(P<0.0001),>50$ $\mu \mathrm{g} / \mathrm{L} \quad(P<0.0001)$ and total exposed $(P<$ $0.0001)$. Statistical association $(\mathrm{r}=0.56, \quad P$ $=0.004$ and $\mathrm{r}=0.44$ and $P=0.008$ ) between water arsenic and urine arsenic was significant among both the exposed groups, consuming arsenic, $<50 \mu \mathrm{g} / \mathrm{L}$ (Fig. 3a) and $>50 \mu \mathrm{g} / \mathrm{L}$ (Fig. $3 b)$ drinking water respectively.

Table 2 presents the urinary porphyrins, uro III, hepta I, and copro III of control and exposed population in arsenic endemic area of West Bengal. It has been found that the variations of uro III between exposed and control groups were found to be significant $(P<0.05)$ in case of both, total male and female. The age-wise total (i.e., combined male and female) in the age range, $<30$ and $>50$ years, the variations of uro III were also significantly higher $(P<0.05)$. In total uro III (i.e. combined male and female), the variation between exposed and control was significant in the exposure range, $>50 \mu \mathrm{g} / \mathrm{L}(P<$ $0.001)$. In the exposed population, the variation between the exposed groups, $<50 \mu \mathrm{g} / \mathrm{L}$ and $>$ $50 \mu \mathrm{g} / \mathrm{L}$ was also found to be significant $(P<$ $0.05)$. Similar variations in significance test as uro III were also observed in case of hepta I. The variations of copro III between exposed and control population were observed to be irregular in the age ranges, $<30$ and $30-<50$ years but significant difference $(P<0.01)$ was observed between exposed and control male of both the exposed groups, who had exposed to W-As, < $50 \mu \mathrm{g} / \mathrm{L}$ and $>50 \mu \mathrm{g} / \mathrm{L}$. A significant difference in copro III with respect to the total (i.e. combined male and female) was observed between controls and exposed, only in age group, $>50$ years.

The urinary porphyrins, hexa I and penta I in control and exposed population of arsenic endemic area are shown in Table 3. The alteration (increase or decrease) in the urinary hexa I and penta I was not found to be regular both for male as well as female. Significant difference $(P<0.05)$ in hexa I was observed only for female of age group, $<30$ years among the exposed group of W-As, > $50 \mu \mathrm{g} / \mathrm{L}$. Significant difference $(P<0.05)$ in penta I was observed for the combined male and female (total) between the two exposure categories, $<50$ and $>50 \mu \mathrm{g} / \mathrm{L}$.

The ratio of porphyrins, copro III to uro III, of control and exposed population in arsenic endemic area of West Bengal is presented in Table 4. The copro III/uro III ratio was noticed to be increased significantly $(P<0.05)$ for the total female and also for the total population (i.e. combined male and female) of age group, > 50 years $(\mathrm{p}<0.05)$.

Table 5 shows the urinary MDA in arsenic exposed and control population in arsenic endemic area of West Bengal. There was a significant $(P<0.05)$ increase in MDA concentration in case of male, when compared between control and the exposed population, having exposure to $\mathrm{W}-\mathrm{As},>50 \mu \mathrm{g} / \mathrm{L}$ in the age range, $30-<50$ years. A significant difference $(P<0.01)$ was also observed when the total control male population was compared to the total exposed male who had exposed to W-As > $50 \mu \mathrm{g} / \mathrm{L}$ and the total exposed group as a whole.

Table 6 presents the correlation co-efficients among different urinary porphyrins, uro III, hepta I, copro III (nmole/g creatinine), ratio of copro III to uro III and arsenic in urine $(\mu \mathrm{g} / \mathrm{g}$ creatinine) of exposed and control population in arsenic endemic area of West Bengal. It was observed that correlation co-efficient was positive in most of the cases except for hexa I and penta I. The negative correlation obtained for the porphyrins, hexa I and penta $I$, is indicated as its gradual decrement with increase in arsenic concentration in urine. It has been also found that individual correlation between urinary U-As and porphyrins for exposed population were always more than that of 
Urinary Porphyrin Profile as Early Biomarker vis-a-vis Malonaldehyde as Oxidative Stress Indicator in Arsenic Exposed Individuals, West Bengal, India

respective control population [Figs. $4 \mathrm{a}, 4 \mathrm{~b}$ for uro III, copro III respectively]. Except hepta I, in all the cases correlation of urinary U-As and porphyrins is good for exposed population than control. A good correlation was observed in the regression analysis between U-As vs uro III and copro III for exposed population.

The correlation coefficients obtained between urinary MDA and urinary arsenic (Table 7). The positive correlation between urinary arsenic and urinary MDA clearly demonstrates MDA levels increase with urinary arsenic among both exposed and control population (Fig. 5).

Table 8 presents' urinary arsenic, urinary porphyrins, uro III, hepta I, hexa I, penta I, copro III, ratio of porphyrins, copro III and uro III and MDA in arsenic exposed population in arsenic endemic area compared to control. Exposed samples were categorised with respect to the urine arsenic levels, < 100, 100-149, 150499 and $\geq 500 \mu \mathrm{g} / \mathrm{g}$ creatinine to observe the simultaneous variations in urinary porphyrins, porphyrin ratios and MDA in different exposed categories. It was found that with increase in arsenic concentration in urine, porphyrins mainly uro III, hepta I, copro III and also MDA had been elevated significantly in male, female and total (combined male and female). However, no significant difference was observed for the ratio, copro III/uro III.

Table1. Arsenic content in urine ( $\mu \mathrm{g} / \mathrm{g}$ Creatinine) according to the arsenic exposure range among control and exposed population in arsenic endemic area of West Bengal

\begin{tabular}{|c|c|c|c|c|}
\hline & W-As, exposure range (n) & Male & Female & Total \\
\hline control & $\begin{array}{l}(\mathrm{nd}-2.4 \mu \mathrm{g} / \mathrm{L}) \\
\mathrm{n}=33\end{array}$ & $\begin{array}{l}2.4 \pm 1.9 \\
27\end{array}$ & $\begin{array}{l}3.0 \pm 2.3 \\
6\end{array}$ & \begin{tabular}{|l}
$2.5 \pm 2.0$ \\
33
\end{tabular} \\
\hline \multirow{3}{*}{ Exposed } & $\begin{array}{l}\text { W-As }<50 \\
(2.4-38.3 \mu \mathrm{g} / \mathrm{L}) \\
\mathrm{n}=24\end{array}$ & $\begin{array}{l}70.4 \pm 49.9 * * * \\
13\end{array}$ & $\begin{array}{l}81.3 \pm 47.4 * * \\
11\end{array}$ & $\begin{array}{l}75.4 \pm 48.0^{* * * *} \\
24\end{array}$ \\
\hline & $\begin{array}{l}\text { W-As }>50 \\
(51.0-1515.0 \mu \mathrm{g} / \mathrm{L}) \\
\mathrm{n}=38\end{array}$ & $\begin{array}{l}309.6 \pm 265.1 * * *, \alpha \\
20\end{array}$ & $\begin{array}{l}320.8 \pm 234.7^{* *},^{\alpha} \\
18\end{array}$ & $\begin{array}{l}314.9 \pm 247.9 * * *,{ }^{\alpha} \\
38\end{array}$ \\
\hline & $\begin{array}{l}\text { Total Exposed } \\
(\mathrm{N}=62)\end{array}$ & $\begin{array}{l}215.4 \pm 238.2 * * * \\
33\end{array}$ & $\begin{array}{l}230.0 \pm 220.0^{*} \\
29\end{array}$ & $\begin{array}{l}222.2 \pm 228.0^{* * * *} \\
62\end{array}$ \\
\hline
\end{tabular}

$n=$ No. of samples

$*$ Significance test between non exposed and exposed population; $*=p<0.05, \quad * *=p<0.01, * * *=p<$

$0.0001,{ }^{\alpha}=$ Significance test between exposed population using $(W-A s<50)$ and $(W-A s>50) ; \alpha=p<0.05, \alpha \alpha$ $=p<0.0001$

nd $=$ not detected

Table2. Urinary porphyrins, uro III, hepta I and copro III (nmol/g creatinine) excreted in control and exposed population in arsenic endemic area of West Bengal.

\begin{tabular}{|c|c|c|c|c|c|c|c|c|c|c|}
\hline \multirow[t]{2}{*}{ Porphyrins } & & \multirow[t]{2}{*}{$\begin{array}{l}\text { Age } \\
\text { range }\end{array}$} & & \multirow[t]{2}{*}{$\begin{array}{c}\text { Control } \\
\text { Mean } \pm \text { SD }\end{array}$} & & \multicolumn{5}{|c|}{$\begin{array}{c}\text { Exposed } \\
\text { Mean } \pm \text { SD }\end{array}$} \\
\hline & & & $\mathrm{n}$ & & $\mathrm{n}$ & W-As $<50$ & $\mathrm{n}$ & W-As $>50$ & $\mathrm{n}$ & Total \\
\hline uro III & $\bar{M}$ & $<30$ & 6 & $4.2 \pm 5.2$ & 5 & $10.6 \pm 6.9$ & 6 & $10.8 \pm 7.3$ & 11 & $10.7 \pm 6.7$ \\
\hline & & $\begin{array}{l}30- \\
<50\end{array}$ & 8 & $9.4 \pm 7.9$ & 5 & $11.8 \pm 12.1$ & 7 & $14.8 \pm 9.0$ & 12 & $13.6 \pm 10.0$ \\
\hline & & $\geq 50$ & 13 & $9.1 \pm 10.3$ & 3 & $15.4 \pm 6.5$ & 7 & $17.4 \pm 9.5$ & 10 & $16.8 \pm 8.4$ \\
\hline & & Total & 27 & $8.1 \pm 8.7$ & 13 & $12.2 \pm 8.7$ & 20 & $14.5 \pm 8.7 *$ & 33 & $13.6 \pm 8.6^{*}$ \\
\hline & $\mathrm{F}$ & $<30$ & 2 & $6.4 \pm 9.0$ & 3 & $9.0 \pm 4.8$ & 3 & $11.0 \pm 1.8$ & 6 & $10.0 \pm 3.4$ \\
\hline & & $\begin{array}{l}30- \\
<50\end{array}$ & 2 & $13.4 \pm 3.8$ & 5 & $9.4 \pm 2.3$ & 12 & $16.7 \pm 8.6$ & 17 & $14.5 \pm 8.0$ \\
\hline & & $\geq 50$ & 2 & $12.3 \pm 4.6$ & 3 & $11.2 \pm 5.3$ & 3 & $20.7 \pm 9.3$ & 6 & $16.0 \pm 8.5$ \\
\hline & & Total & 6 & $10.7 \pm 5.9$ & 11 & $9.8 \pm 3.6^{\alpha}$ & 18 & $16.4 \pm 8.15$ & 29 & $13.9 \pm 7.5$ \\
\hline & $\mathrm{T}$ & $<30$ & 8 & $4.7 \pm 5.7$ & 8 & $10.0 \pm 5.9$ & 9 & $10.9 \pm 5.8^{*}$ & 17 & $10.5 \pm 5.7 *$ \\
\hline & & $\begin{array}{l}30- \\
<50\end{array}$ & 10 & $10.2 \pm 7.3$ & 10 & $10.6 \pm 8.3$ & 19 & $16.0 \pm 8.5$ & 29 & $14.1 \pm 8.7$ \\
\hline & & $\geq 50$ & 15 & $9.5 \pm 9.7$ & 6 & $13.3 \pm 5.8$ & 10 & $18.4 \pm 9.0 *$ & 16 & $16.5 \pm 8.2 *$ \\
\hline & & Total & 33 & $8.6 \pm 8.2$ & 24 & $11.1 \pm 6.8^{\alpha}$ & 38 & $15.4 \pm 8.4^{* * *}$ & 62 & $13.7 \pm 8.0 * *$ \\
\hline
\end{tabular}


Urinary Porphyrin Profile as Early Biomarker vis-a-vis Malonaldehyde as Oxidative Stress Indicator in Arsenic Exposed Individuals, West Bengal, India

\begin{tabular}{|c|c|c|c|c|c|c|c|c|c|c|}
\hline \multirow{13}{*}{ hepta I } & & & & & & & & & & \\
\hline & $\mathrm{M}$ & $<30$ & 6 & nd & 5 & $2.3 \pm 1.6$ & 6 & $2.2 \pm 2.5$ & 11 & $2.3 \pm 2.0$ \\
\hline & & $\begin{array}{l}30- \\
<50\end{array}$ & 8 & $1.8 \pm 2.2$ & 5 & $3.7 \pm 3.6$ & 7 & $5.4 \pm 5.5$ & 12 & $4.7 \pm 4.7$ \\
\hline & & $\geq 50$ & 13 & $2.4 \pm 4.2$ & 3 & $4.5 \pm 2.3$ & 7 & $5.2 \pm 5.7$ & 10 & $5.0 \pm 4.8$ \\
\hline & & Total & 27 & $1.7 \pm 3.2$ & 13 & $3.4 \pm 2.6$ & 20 & $4.4 \pm 4.9 *$ & 33 & $4.0 \pm 4.1 *$ \\
\hline & $\mathrm{F}$ & $<30$ & 2 & $1.4 \pm 0.4$ & 3 & $3.3 \pm 1.6$ & 3 & $5.0 \pm 4.6$ & 6 & $4.1 \pm 3.2$ \\
\hline & & $\begin{array}{l}30- \\
<50\end{array}$ & 2 & $2.7 \pm 0.9$ & 5 & $5.1 \pm 5.8$ & 12 & $4.1 \pm 3.3$ & 17 & $4.4 \pm 4.0$ \\
\hline & & $\geq 50$ & 2 & $0.9 \pm 1.3$ & 3 & $2.5 \pm 2.1$ & 3 & $4.0 \pm 2.3$ & 6 & $3.2 \pm 2.1$ \\
\hline & & Total & 6 & $1.7 \pm 1.1$ & 11 & $3.9 \pm 4.0$ & 18 & $4.2 \pm 3.2$ & 29 & $4.1 \pm 3.5$ \\
\hline & $\mathrm{T}$ & $<30$ & 8 & $0.4 \pm 0.7$ & 8 & $2.7 \pm 1.6^{*}$ & 9 & $3.1 \pm 3.3^{*}$ & 17 & $2.9 \pm 2.6^{*}$ \\
\hline & & $\begin{array}{l}30- \\
<50\end{array}$ & 10 & $2.0 \pm 2.0$ & 10 & $4.4 \pm 4.6$ & 19 & $4.6 \pm 4.1$ & 29 & $4.5 \pm 4.2$ \\
\hline & & $\geq 50$ & 15 & $2.2 \pm 4.0$ & 6 & $3.5 \pm 2.3$ & 10 & $4.8 \pm 4.8$ & 16 & $4.3 \pm 4.0$ \\
\hline & & Total & 33 & $1.7 \pm 3.0$ & 24 & $3.6 \pm 3.3^{*}$ & 38 & $4.3 \pm 4.1 *$ & 62 & $4.0 \pm 3.8^{*}$ \\
\hline \multirow[t]{12}{*}{ copro III } & $\mathrm{M}$ & $<30$ & 6 & $24.6 \pm 14.7$ & 5 & $12.0 \pm 5.5$ & 6 & $24.2 \pm 21.3$ & 11 & $18.6 \pm 16.7$ \\
\hline & & $\begin{array}{l}30- \\
<50\end{array}$ & 8 & $17.8 \pm 15.8$ & 5 & $16.7 \pm 16.9$ & 7 & $15.8 \pm 21.2$ & 12 & $16.2 \pm 18.7$ \\
\hline & & $\geq 50$ & 13 & $10.0 \pm 9.5$ & 3 & $29.1 \pm 6.2 * *$ & 7 & $38.6 \pm 23.4 * *$ & 10 & $35.8 \pm 19.9$ *** \\
\hline & & Total & 27 & $15.5 \pm 13.6$ & 13 & $17.8 \pm 12.6$ & 20 & $26.3 \pm 23.1$ & 33 & $22.9 \pm 19.8$ \\
\hline & $\mathrm{F}$ & $<30$ & 2 & $88+125$ & 3 & $108+21$ & 3 & $102+800$ & 6 & $105+52$ \\
\hline & & $\begin{array}{l}30- \\
<50\end{array}$ & 2 & $11.2 \pm 3.4$ & 5 & $20.5 \pm 9.5$ & 12 & $22.9 \pm 16.9$ & 17 & $22.2 \pm 14.9$ \\
\hline & & $\geq 50$ & 2 & $10.7 \pm 6.4$ & 3 & $23.5 \pm 7.1$ & 3 & $15.6 \pm 8.3$ & 6 & $19.6 \pm 8.1$ \\
\hline & & Total & 6 & $10.2 \pm 6.5$ & 11 & $18.7 \pm 8.6$ & 18 & $19.6 \pm 15.1$ & 29 & $19.2 \pm 12.8$ \\
\hline & $\mathrm{T}$ & $<30$ & 8 & $20.6 \pm 15.1$ & 8 & $11.5 \pm 4.4$ & 9 & $19.5 \pm 18.6$ & 17 & $15.8 \pm 14.1$ \\
\hline & & $\begin{array}{l}30- \\
<50\end{array}$ & 10 & $16.5 \pm 14.2$ & 10 & $18.6 \pm 13.1$ & 19 & $20.3 \pm 18.4$ & 29 & $19.7 \pm 16.5$ \\
\hline & & $\geq 50$ & 15 & $10.1 \pm 9.0$ & 6 & $26.3 \pm 6.7 * * *$ & 10 & $31.7 \pm 22.5^{* *}$ & 16 & $29.7 \pm 18.0 * * *$ \\
\hline & & Total & 33 & $14.6 \pm 12.7$ & 24 & $18.2 \pm 10.7$ & 38 & $23.1 \pm 19.7$ & 62 & $21.2 \pm 16.9$ \\
\hline
\end{tabular}

$*=$ Significance test between exposed and control population; $*=p<0.05, * *=p<0.01, * * *=p<0.001$,

${ }^{\alpha}=$ Significance test between exposed population using (W-As <50) and $(W-A s>50) ; \alpha=p<0.05$

M=Male, F=Female, $T=$ Total

Table3. Urinary porphyrins, hexa I and penta I (nmol/g creatinine) excreted in arsenic control and exposed population in arsenic endemic area of West Bengal.

\begin{tabular}{|c|c|c|c|c|c|c|c|c|c|c|}
\hline \multirow[t]{2}{*}{ Porphyrins } & & \multirow[t]{2}{*}{ Age range } & \multicolumn{2}{|c|}{$\begin{array}{l}\text { Control } \\
\text { Mean } \pm \mathrm{SD}\end{array}$} & \multicolumn{6}{|c|}{$\begin{array}{l}\text { Exposed } \\
\text { Mean } \pm \text { SD }\end{array}$} \\
\hline & & & $\mathrm{n}$ & & $\mathrm{n}$ & $(\mathrm{W}-\mathrm{As}<50)$ & $\mathrm{n}$ & $(\mathrm{W}-\mathrm{As}>50)$ & $\mathrm{n}$ & Total \\
\hline \multirow[t]{12}{*}{ hexa I } & M & $<30$ & 6 & nd & 5 & nd & 6 & $0.7 \pm 1.6$ & 11 & $0.4 \pm 1.2$ \\
\hline & & $30-<50$ & 8 & $1.3 \pm 1.8$ & 5 & $0.9 \pm 2.1$ & 7 & $0.4 \pm 1.1$ & 12 & $0.6 \pm 1.5$ \\
\hline & & $\geq 50$ & 13 & $0.7 \pm 2.1$ & 3 & $0.3 \pm 0.1$ & 7 & $0.1 \pm 0.2$ & 10 & $0.1 \pm 0.2$ \\
\hline & & Total & 27 & $0.7 \pm 1.8$ & 13 & $0.4 \pm 1.3$ & 20 & $0.4 \pm 1.1$ & 33 & $0.4 \pm 1.1$ \\
\hline & $\mathrm{F}$ & $<30$ & 2 & $0.5 \pm 0.4$ & 3 & $0.2 \pm 0.2$ & 3 & $0.7 \pm 0.1 *$ & 6 & $0.5 \pm 0.3$ \\
\hline & & $30-<50$ & 2 & nd & 5 & $1.6 \pm 2.5$ & 12 & $0.5 \pm 1.6$ & 17 & $0.8 \pm 1.9$ \\
\hline & & $\geq 50$ & 2 & nd & 3 & nd & 3 & nd & 6 & nd \\
\hline & & Total & 6 & $0.2 \pm 0.3$ & 11 & $0.8 \pm 1.8$ & 18 & $0.5 \pm 1.3$ & 29 & $0.6 \pm 1.40$ \\
\hline & $\mathrm{T}$ & $<30$ & 8 & $0.1 \pm 0.3$ & 8 & $0.1 \pm 0.2$ & 9 & $0.7 \pm 1.3$ & 17 & $0.4 \pm 1.0$ \\
\hline & & $30-<50$ & 10 & $1.0 \pm 1.7$ & 10 & $1.3 \pm 2.2$ & 19 & $0.5 \pm 1.4$ & 29 & $0.8 \pm 1.7$ \\
\hline & & $\geq 50$ & 15 & $0.6 \pm 2.0$ & 6 & $0.1 \pm 0.2$ & 10 & $0.05 \pm 0.1$ & 16 & $0.1 \pm 0.2$ \\
\hline & & Total & 33 & $0.6 \pm 1.6$ & 24 & $0.6 \pm 1.5$ & 38 & $0.4 \pm 1.2$ & 62 & $0.5 \pm 1.3$ \\
\hline penta I & $M$ & $<30$ & 6 & nd & 5 & $0.5 \pm 0.5 *$ & 6 & $0.8 \pm 1.0$ & 11 & $0.7 \pm 0.8$ \\
\hline
\end{tabular}


Urinary Porphyrin Profile as Early Biomarker vis-a-vis Malonaldehyde as Oxidative Stress Indicator in Arsenic Exposed Individuals, West Bengal, India

\begin{tabular}{|l|l|l|l|l|l|l|l|l|l|l|}
\hline & & $30-<50$ & 8 & $0.4 \pm 0.7$ & 5 & $1.9 \pm 2.6$ & 7 & $0.5 \pm 0.6$ & 12 & $1.1 \pm 1.8$ \\
\hline & & $\geq 50$ & 13 & $2.8 \pm 7.88$ & 3 & $2.0 \pm 0.4$ & 7 & $1.8 \pm 2.6$ & 10 & $1.9 \pm 2.1$ \\
\hline & & Total & 27 & $1.4 \pm 5.5$ & 13 & $1.4 \pm 1.7$ & 20 & $1.0 \pm 1.7$ & 33 & $1.2 \pm 1.7$ \\
\hline & F & $<30$ & 2 & $1.8 \pm 2.5$ & 3 & $6.1 \pm 6.7$ & 3 & $0.9 \pm 1.1$ & 6 & $3.5 \pm 5.1$ \\
\hline & & $30-<50$ & 2 & $0.3 \pm 0.4$ & 5 & $3.3 \pm 5.2$ & 12 & $0.5 \pm 1.0$ & 17 & $1.3 \pm 3.1$ \\
\hline & & $\geq 50$ & 2 & $2.4 \pm 3.4$ & 3 & nd & 3 & $1.3 \pm 1.3$ & 6 & $0.6 \pm 1.1$ \\
\hline & & Total & 6 & $1.5 \pm 2.1$ & 11 & $3.2 \pm 5.1$ & 18 & $0.7 \pm 1.1$ & 29 & $1.6 \pm 3.4$ \\
\hline & T & $<30$ & 8 & $0.4 \pm 1.2$ & 8 & $2.6 \pm 4.6$ & 9 & $0.8 \pm 1.0$ & 17 & $1.7 \pm 3.3$ \\
\hline & & $30-<50$ & 10 & $0.3 \pm 0.6$ & 10 & $2.6 \pm 4.0^{\alpha}$ & 19 & $0.5 \pm 0.9$ & 29 & $1.2 \pm 2.6$ \\
\hline & & $\geq 50$ & 15 & $2.7 \pm 7.3$ & 6 & $1.0 \pm 1.1$ & 10 & $1.7 \pm 2.2$ & 16 & $1.4 \pm 1.9$ \\
\hline & & Total & 33 & $1.5 \pm 5.0$ & 24 & $2.2 \pm 3.7^{\alpha}$ & 38 & $0.9 \pm 1.4$ & 62 & $1.4 \pm 2.6$ \\
\hline
\end{tabular}

$*=$ Significance test between exposed and control population; $*=p<0.05$,

${ }^{\alpha}=$ Significance test between exposed population using (W-As <50) and (W-As> 50); $\alpha=p<0.05$

Table 4.The ratio of porphyrins, copro III and uro III of control and exposed population in arsenic endemic area of West Bengal.

\begin{tabular}{|c|c|c|c|c|c|c|c|c|c|c|}
\hline \multirow[t]{2}{*}{ Ratio of Porphyrins } & & & \multicolumn{2}{|c|}{$\begin{array}{l}\text { Control } \\
\text { Mean } \pm \text { SD }\end{array}$} & \multicolumn{6}{|c|}{$\begin{array}{l}\text { Exposed } \\
\text { Mean } \pm \text { SD }\end{array}$} \\
\hline & & & $\mathrm{n}$ & & $\mathrm{n}$ & W-As $<50$ & $\mathrm{n}$ & W-As $>50$ & $\mathrm{n}$ & Total \\
\hline \multirow{12}{*}{ copro III/uro III } & $M$ & $<30$ & 6 & $2.2 \pm 3.3$ & 5 & $0.9 \pm 0.5$ & 6 & $1.2 \pm 1.2$ & 11 & $1.0 \pm 0.9$ \\
\hline & & $30-<50$ & 8 & $1.6 \pm 1.5$ & 5 & $1.9 \pm 2.2$ & 7 & $1.1 \pm 0.8$ & 12 & $1.4 \pm 1.5$ \\
\hline & & $\geq 50$ & 13 & $1.2 \pm 1.7$ & 3 & $2.0 \pm 0.5$ & 7 & $2.7 \pm 1.6$ & 10 & $2.5 \pm 1.4$ \\
\hline & & Total & 27 & $1.5 \pm 2.0$ & 13 & $1.5 \pm 1.4$ & 20 & $1.7 \pm 1.4$ & 33 & $1.6 \pm 1.4$ \\
\hline & $\mathrm{F}$ & $<30$ & 2 & $0.7 \pm 1.0$ & 3 & $1.5 \pm 0.9$ & 3 & $0.9 \pm 0.7$ & 6 & $1.2 \pm 0.8$ \\
\hline & & $30-<50$ & 2 & $0.8 \pm 0.0$ & 5 & $2.4 \pm 1.8$ & 12 & $1.5 \pm 1.2$ & 17 & $1.8 \pm 1.4$ \\
\hline & & $\geq 50$ & 2 & $0.8 \pm 0.2$ & 3 & $2.7 \pm 2.0$ & 3 & $0.9 \pm 0.6$ & 6 & $1.8 \pm 1.6$ \\
\hline & & Total & 6 & $0.8 \pm 0.5$ & 11 & $2.2 \pm 1.6^{*}$ & 18 & $1.3 \pm 1.0$ & 29 & $1.7 \pm 1.4$ \\
\hline & $\mathrm{T}$ & $<30$ & 8 & $1.8 \pm 2.9$ & 8 & $1.1 \pm 0.7$ & 9 & $1.1 \pm 1.0$ & 17 & $1.1 \pm 0.8$ \\
\hline & & $30-<50$ & 10 & $1.5 \pm 1.3$ & 10 & $2.1 \pm 1.9$ & 19 & $1.3 \pm 1.0$ & 29 & $1.6 \pm 1.4$ \\
\hline & & $\geq 50$ & 15 & $1.1 \pm 1.6$ & 6 & $2.3 \pm 1.3$ & 10 & $2.1 \pm 1.6$ & 16 & $2.2 \pm 1.4^{*}$ \\
\hline & & Total & 33 & $1.4 \pm 1.9$ & 24 & $1.9 \pm 1.5$ & 38 & $1.5 \pm 1.2$ & 62 & $1.6 \pm 1.3$ \\
\hline
\end{tabular}

$*=$ Significance test between exposed and control population; $*=p<0.05$

Table5. Concentration of urinary MDA ( $\mu$ mol/g creatinine) excreted in control and exposed population in arsenic endemic area of West Bengal.

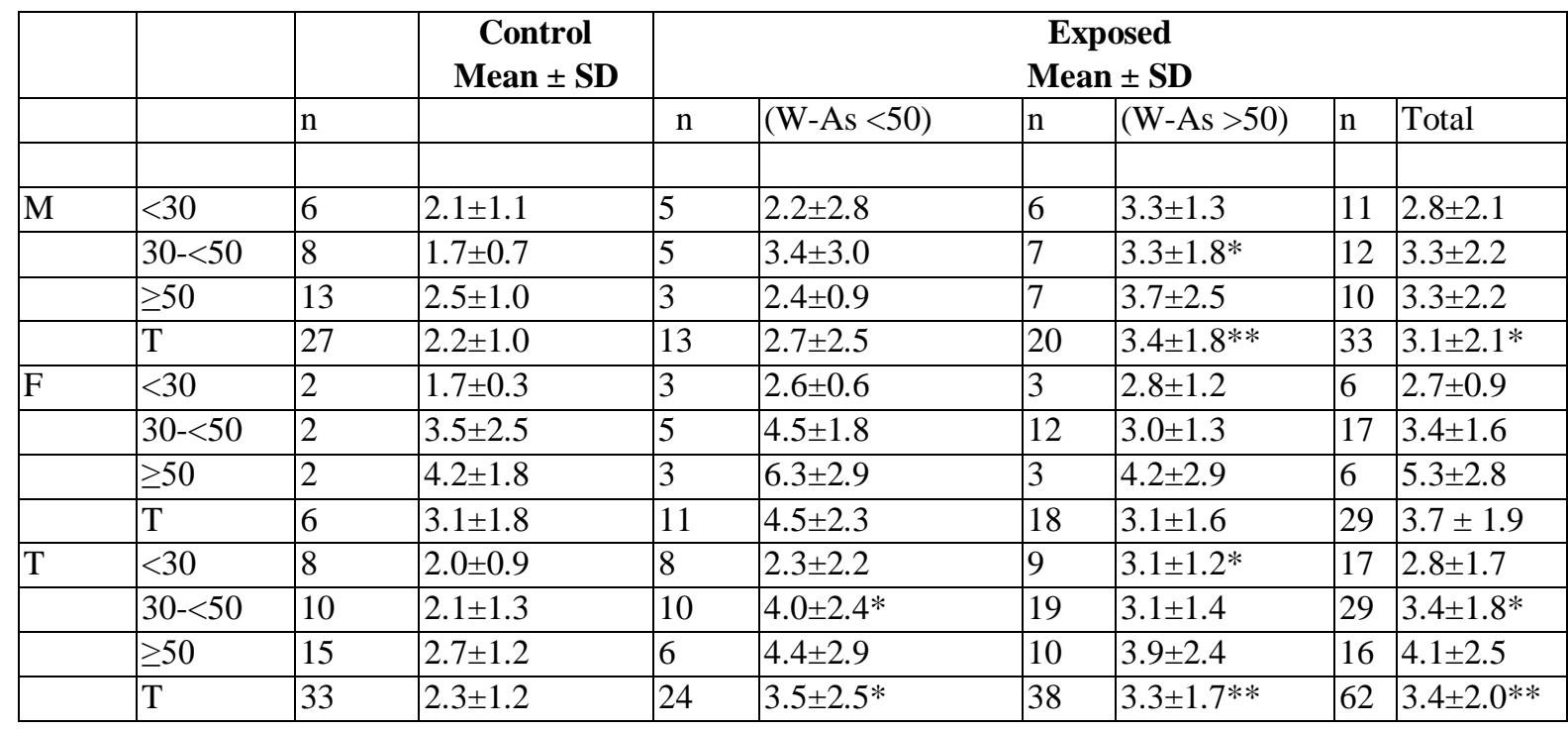

$*=$ Significance test between exposed and control population; $*=p<0.05, * *=p<0.01$, 
Urinary Porphyrin Profile as Early Biomarker vis-a-vis Malonaldehyde as Oxidative Stress Indicator in Arsenic Exposed Individuals, West Bengal, India

Table 6. Correlation analysis between urinary arsenic ( $\mu \mathrm{g} / \mathrm{g}$ creatinine) and urinary porphyrines ( $\mathrm{nmol} / \mathrm{g}$ creatinine) in arsenic control and exposed subjects

\begin{tabular}{|c|c|c|c|c|c|c|c|c|c|c|c|c|c|}
\hline \multirow[t]{3}{*}{ Porphyrins } & & \multicolumn{3}{|c|}{$\begin{array}{l}\text { Control } \\
\text { Mean } \pm \text { SD }\end{array}$} & \multicolumn{9}{|c|}{$\begin{array}{l}\text { Exposed } \\
\text { Mean } \pm \text { SD }\end{array}$} \\
\hline & & \multirow[b]{2}{*}{ n } & \multirow[b]{2}{*}{$\mathrm{R}$ value } & \multirow[b]{2}{*}{$\mathrm{P}$ value } & \multicolumn{3}{|c|}{$(\mathrm{W}-\mathrm{As}<50)$} & \multicolumn{3}{|c|}{$(\mathrm{W}-\mathrm{As}>50)$} & \multicolumn{3}{|c|}{ Total } \\
\hline & & & & & $\mathrm{n}$ & $\mathrm{R}$ value & $\mathrm{P}$ value & $\mathrm{n}$ & $\mathrm{R}$ value & $\mathrm{P}$ value & $n$ & $\begin{array}{l}\mathrm{R} \\
\text { value }\end{array}$ & $\begin{array}{l}\mathrm{P} \\
\text { value }\end{array}$ \\
\hline \multirow[t]{3}{*}{ uro III } & $\mathrm{M}$ & 27 & 0.08 & 0.709 & 13 & 0.35 & 0.244 & 20 & 0.315 & 0.203 & 33 & 0.29 & 0.113 \\
\hline & $\mathrm{F}$ & 6 & 0.59 & 0.216 & 11 & 0.37 & 0.268 & 18 & 0.46 & 0.063 & 29 & 0.57 & 0.001 \\
\hline & $\mathrm{T}$ & 33 & 0.17 & 0.369 & 24 & 0.3 & 0.150 & 38 & 0.39 & 0.022 & 62 & 0.42 & 0.001 \\
\hline \multirow[t]{3}{*}{ hepta I } & $\mathrm{M}$ & 27 & 0.228 & 0.272 & 13 & 0.22 & 0.511 & 20 & 0.129 & 0.621 & 33 & 0.17 & 0.397 \\
\hline & $\mathrm{F}$ & 6 & 0.28 & 0.648 & 11 & 0.13 & 0.711 & 18 & 0.27 & 0.318 & 29 & 0.2 & 0.328 \\
\hline & $\mathrm{T}$ & 33 & 0.19 & 0.328 & 24 & 0.19 & 0.411 & 38 & 0.181 & 0.322 & 62 & 0.18 & 0.189 \\
\hline \multirow[t]{3}{*}{ hexa I } & $\mathrm{M}$ & 27 & 0.160 & 0.456 & 13 & -0.17 & 0.763 & 20 & -0.18 & 0.507 & 33 & -0.097 & 0.603 \\
\hline & $\mathrm{F}$ & 6 & -0.42 & 0.408 & 11 & 0.14 & 0.698 & 18 & -0.37 & 0.152 & 29 & -0.16 & 0.423 \\
\hline & $\mathrm{T}$ & 33 & 0.07 & 0.749 & 24 & 0.11 & 0.594 & 38 & -0.188 & 0.287 & 62 & 0.125 & 0.348 \\
\hline \multirow[t]{3}{*}{ penta I } & $\mathrm{M}$ & 27 & 0.225 & 0.280 & 13 & -0.15 & 0.649 & 20 & -0.10 & 0.691 & 33 & -0.113 & 0.552 \\
\hline & $\mathrm{F}$ & 6 & -0.50 & 0.310 & 11 & -0.18 & 0.595 & 18 & -0.29 & 0.265 & 29 & 0.260 & 0.174 \\
\hline & $\mathrm{T}$ & 33 & 0.15 & 0.433 & 24 & 0.09 & 0.681 & 38 & -0.17 & 0.342 & 62 & 0.19 & 0.154 \\
\hline \multirow[t]{3}{*}{ copro III } & $\mathrm{M}$ & 27 & 0.142 & 0.507 & 13 & 0.36 & 0.251 & 20 & 0.36 & 0.143 & 33 & 0.38 & 0.038 \\
\hline & $\mathrm{F}$ & 6 & 0.64 & 0.173 & 11 & 0.49 & 0.123 & 18 & 0.41 & 0.112 & 29 & 0.38 & 0.049 \\
\hline & $\mathrm{T}$ & 33 & 0.14 & 0.455 & 24 & 0.4 & 0.059 & 38 & 0.38 & 0.028 & 62 & 0.38 & 0.004 \\
\hline \multirow{3}{*}{\begin{tabular}{|ll} 
Copro & III/ \\
uro III & \\
\end{tabular}} & $\mathrm{M}$ & 27 & 0.11 & 0.629 & 13 & 0.32 & 0.310 & 20 & 0.30 & 0.241 & 33 & 0.27 & 0.162 \\
\hline & $\mathrm{F}$ & 6 & 0.53 & 0.275 & 11 & 0.21 & 0.523 & 18 & 0.32 & 0.226 & 29 & 0.13 & 0.954 \\
\hline & $\mathrm{T}$ & 33 & 0.096 & 0.619 & 24 & 0.3 & 0.164 & 38 & 0.28 & 0.118 & 62 & 0.13 & 0.327 \\
\hline
\end{tabular}

Table7.Correlation analysis between urinary arsenic ( $\mu \mathrm{g} / \mathrm{g}$ creatinine) and urinary MDA ( $\mu$ mol/g creatinine) in arsenic control and exposed subjects

\begin{tabular}{|c|c|c|c|c|c|c|c|c|c|c|c|c|}
\hline & \multicolumn{3}{|c|}{$\begin{array}{c}\text { Control } \\
\text { Mean } \pm \text { SD }\end{array}$} & \multicolumn{9}{|c|}{$\begin{array}{c}\text { Exposed } \\
\text { Mean } \pm \text { SD }\end{array}$} \\
\hline & \multirow[b]{2}{*}{$\mathrm{n}$} & \multirow[b]{2}{*}{$\mathrm{R}$ value } & \multirow[b]{2}{*}{$\mathrm{P}$ value } & \multicolumn{3}{|c|}{$(\mathrm{W}-\mathrm{As}<50)$} & \multicolumn{3}{|c|}{$(\mathrm{W}-\mathrm{As}>50)$} & \multicolumn{3}{|c|}{ Total } \\
\hline & & & & $\mathrm{n}$ & $\mathrm{R}$ value & $\mathrm{P}$ value & $\mathrm{n}$ & $\mathrm{R}$ value & $\mathrm{P}$ value & $\mathrm{n}$ & $\mathrm{R}$ value & $\mathrm{P}$ value \\
\hline M & 27 & 0.60 & 0.001 & 13 & 0.68 & $<0.01$ & 20 & 0.62 & $<0.01$ & 33 & 0.64 & $<0.01$ \\
\hline $\mathrm{F}$ & 6 & 0.56 & 0.252 & 11 & 0.80 & $<0.01$ & 18 & 0.46 & 0.006 & 29 & 0.19 & 0.330 \\
\hline $\mathrm{T}$ & 33 & 0.59 & $<0.01$ & 24 & 0.75 & $<0.01$ & 38 & 0.43 & 0.008 & 62 & 0.40 & 0.003 \\
\hline
\end{tabular}

Table8. Arsenic content in urine ( $\mu \mathrm{g} / \mathrm{g}$ Creatinine), urinary porphyrins, uro III, hepta I, hexa I, penta I, copro III (nmol/g creatinine), ratio of porphyrins, Copro III and uro III and urinary MDA ( $\mu$ mol/g creatinine) among exposed and control population in arsenic endemic area of West Bengal.

\begin{tabular}{|c|c|c|c|c|c|c|c|c|c|c|c|}
\hline & $\begin{array}{c}\text { Urine- } \\
\text { As }\end{array}$ & $\mathbf{N}$ & & Urine-As & Uro III & Hpta I & Hха I & Pnta I & Cpro II & $\begin{array}{c}\text { Cpro } \\
\text { III/uro } \\
\text { III }\end{array}$ & MDA \\
\hline \multirow{3}{*}{ Control } & & 27 & M & $2.4 \pm 1.9$ & $8.1 \pm 8.7$ & $1.7 \pm 3.2$ & $0.7 \pm 1.8$ & $1.4 \pm 5.5$ & $15.5 \pm 13.6$ & $1.5 \pm 2.0$ & $2.2 \pm 1.0$ \\
\hline & & 6 & $\mathrm{~F}$ & $3.0 \pm 2.3$ & $10.7 \pm 5.9$ & $1.7 \pm 1.1$ & $0.2 \pm 0.3$ & $1.5 \pm 2.1$ & $10.2 \pm 6.5$ & $0.8 \pm 0.5$ & $2.0 \pm 0.9$ \\
\hline & & 33 & $\mathrm{~T}$ & $2.5 \pm 2.0$ & $8.6 \pm 8.2$ & $1.7 \pm 3.0$ & $0.6 \pm 1.6$ & $1.5 \pm 5.00$ & $14.6 \pm 12.7$ & $1.4 \pm 1.9$ & $2.3 \pm 1.2$ \\
\hline \multirow{6}{*}{ Exposed } & $<100$ & 12 & $\mathrm{M}$ & $50.1 \pm 29.7$ & $10.1 \pm 7.4$ & $2.6 \pm 2.3$ & $0.6 \pm 1.3$ & $0.9 \pm 0.8$ & $11.6 \pm 10.8$ & $1.3 \pm 1.5$ & $2.1 \pm 1.6$ \\
\hline & & 12 & $\mathrm{~F}$ & $65.6 \pm 27.2$ & $8.3 \pm 2.9$ & $3.7 \pm 3.2$ & $0.6 \pm 1.3$ & $2.3 \pm 3.9$ & $12.5 \pm 7.0$ & $1.7 \pm 1.4$ & $3.0 \pm 1.4$ \\
\hline & & 24 & $\mathrm{~T}$ & $57.8 \pm 29.0$ & $9.2 \pm 5.5$ & $3.2 \pm 2.8$ & $0.6 \pm 1.3$ & $1.6 \pm 2.9$ & $12.0 \pm 8.9$ & $1.5 \pm 1.4$ & $2.5 \pm 1.5$ \\
\hline & \begin{tabular}{|l}
$100-$ \\
149
\end{tabular} & 5 & $\mathrm{M}$ & $130.4 \pm 14.7$ & $10.3 \pm 2.9$ & $2.3 \pm 1.7$ & $0 \pm 0$ & $1.2 \pm 0.6$ & $18.8 \pm 15.8$ & $2.0 \pm 1.7$ & $2.7 \pm 1.3$ \\
\hline & & 4 & $\mathrm{~F}$ & $121.6 \pm 13.4$ & $7.9 \pm 3.9$ & $1.4 \pm 1.5$ & $0 \pm 0$ & $1.0 \pm 1.1$ & $14.3 \pm 9.5$ & $2.0 \pm 2.0$ & $4.0 \pm 1.6^{*}$ \\
\hline & & 9 & $\mathrm{~T}$ & $126.5 \pm 14.0$ & $9.3 \pm 3.4$ & $1.9 \pm 1.6$ & $0 \pm 0$ & $1.1 \pm 0.8$ & $16.8 \pm 12.8$ & $2.0 \pm 1.7$ & $3.3 \pm 1.5$ \\
\hline
\end{tabular}


Urinary Porphyrin Profile as Early Biomarker vis-a-vis Malonaldehyde as Oxidative Stress Indicator in Arsenic Exposed Individuals, West Bengal, India

\begin{tabular}{|l|l|l|l|l|l|l|l|l|l|l|l|}
\hline & $\begin{array}{l}150- \\
499\end{array}$ & 11 & $\mathrm{M}$ & $237.9 \pm 76.4$ & $10.1 \pm 6.5$ & $4.1 \pm 5.0$ & $0.2 \pm 0.7$ & $0.5 \pm 1.5$ & $20.8 \pm 22.7$ & $2.0 \pm 1.4$ & $\begin{array}{l}4.3 \pm 2.4^{*} \\
* *\end{array}$ \\
\hline & 9 & $\mathrm{~F}$ & $259 \pm 69.6$ & $13.4 \pm 5.6$ & $4.2 \pm 2.2 *$ & $0.1 \pm 0.2$ & $0.7 \pm 0.9$ & $17.8 \pm 14.4$ & $1.4 \pm 0.8$ & $4.2 \pm 2.5$ \\
\hline & 20 & $\mathrm{~T}$ & $247.4 \pm 72.3$ & $11.6 \pm 6.2$ & $4.1 \pm 3.8 *$ & $0.1 \pm 0.5$ & $0.6 \pm 1.3$ & $19.4 \pm 18.8$ & $1.7 \pm 1.2$ & $\begin{array}{l}4.2 \pm 2.4 * \\
*\end{array}$ \\
\cline { 2 - 10 } & $\geq 500$ & 3 & $\mathrm{M}$ & $771.8 \pm 337.2$ & $16.2 \pm 2.9$ & $4.7 \pm 0.9$ & $0.1 \pm 0.2$ & $0 \pm 0$ & $30.0 \pm 15.1$ & $2.0 \pm 1.6$ & $\begin{array}{l}7.0 \pm 1.9 * \\
*\end{array}$ \\
\hline & 4 & $\mathrm{~F}$ & $696.6 \pm 166.4$ & $17.5 \pm 9.5$ & $3.5 \pm 4.0$ & $0 \pm 0$ & $0 \pm 0$ & $23.4 \pm 6.1 *$ & $2.0 \pm 2.0$ & $\begin{array}{l}4.6 \pm 0.6^{*} \\
*\end{array}$ \\
\hline
\end{tabular}

$*$ Significance test between exposed and control population; $*=\mathrm{p}<0.05, * *=\mathrm{p}<0.001 * * *=\mathrm{p}<0.0001$,
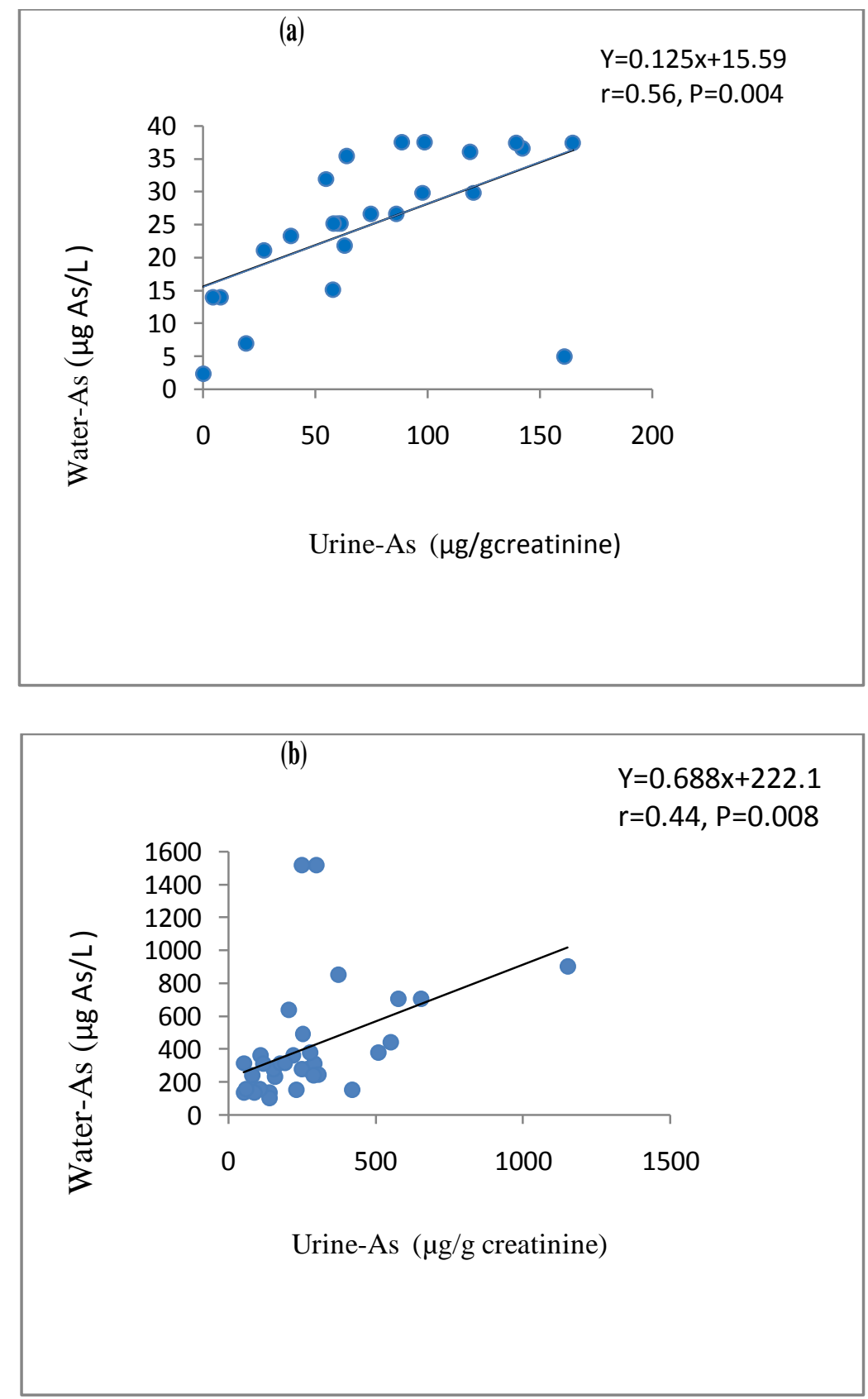

Figure3. Correlation between Water-As and Urine-As of (a) exposed population $W$-As $<50 \mu g$ As/L and $(b)$ exposed population W-As > 50 $\mathrm{g}$ As/L in N-24 Parganas district, West Bengal. 
Urinary Porphyrin Profile as Early Biomarker vis-a-vis Malonaldehyde as Oxidative Stress Indicator in Arsenic Exposed Individuals, West Bengal, India
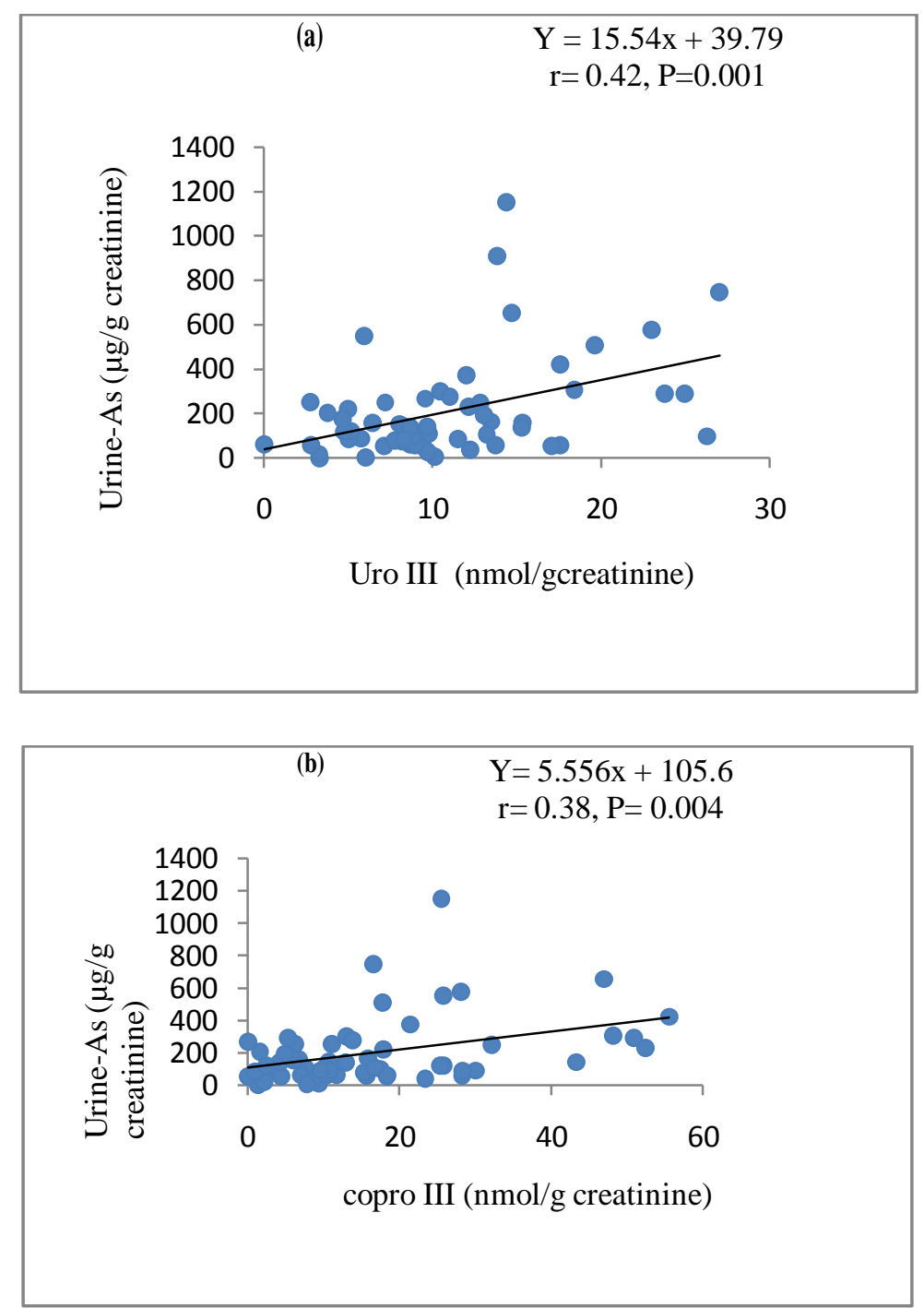

Figure4. Correlation between Porphyrines and Urine-As of (a) uro III , (b) copro III in N-24 Parganas district, West Bengal.

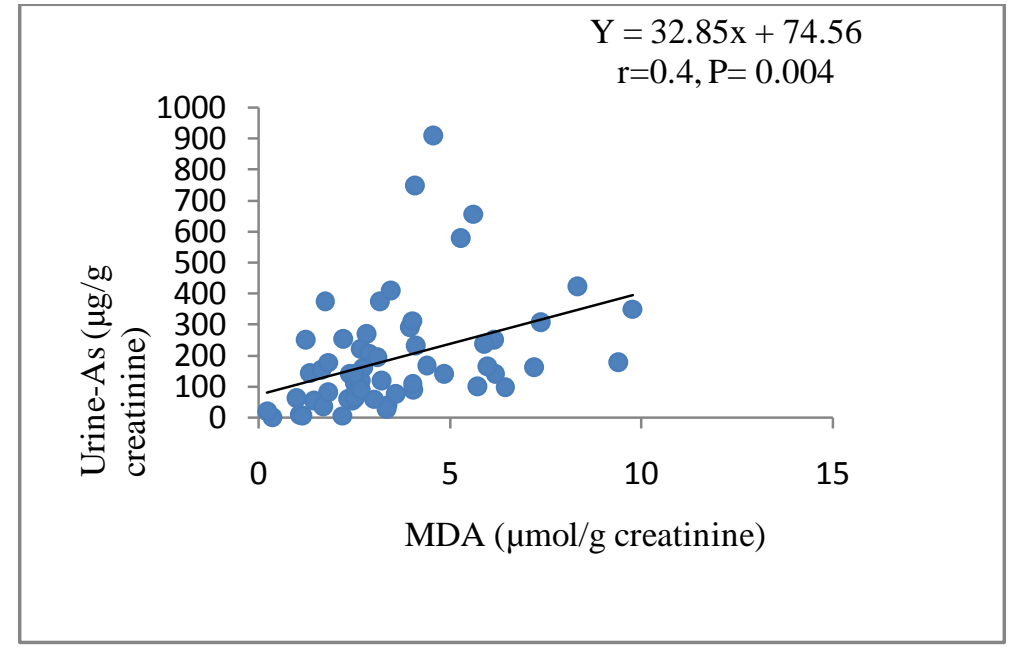

Figure5. Correlation between MDA and Urine-As for selected subjects in N-24 Parganas district, West Bengal

\subsection{Examination of Arsenicosis}

Arsenicosis examination of the study groups was undertaken as per the WHO diagnostic criteria (i.e. pigmentation and keratosis along with evidence of water arsenic exposure above permissible limit) and the details of the same will be published elsewhere. The examination 
report indicated definite arsenicosis among 4.9 $\%$ of exposed group which fulfill the WHO criteria [42].

The present study reports urine arsenic as the current exposure biomarker, five porphyrins, uro III, hepta I, hexa I, penta I and copro III as biomarkers of toxic effects due to exposure to arsenic and MDA as a biomarker of oxidative stress among population in arsenic endemic area of West Bengal. The porphyrins and MDA levels were compared with drinking water arsenic level as well as urine arsenic of exposed and control population. Urine arsenic was found to increase with increased arsenic concentration in drinking water (Table 1). It was also noticed that the urinary arsenic was more in female compared to male which may be accounted due to the fact that they spend most of their time in home and consume the same contaminated water whereas the male usually go out for work and take water having different arsenic levels. Significant difference in urine arsenic was observed between exposed and control population of both, male and female.

The urinary excretion of porphyrins, uro III, hepta I, and copro III, mostly elevated with increased arsenic concentration in drinking water (Table 2.) irrespective of gender and age including the total specific porphyrins (combined male and female) was compared with control but to different degrees in the arsenic endemic area. These three porphyrins exhibited highest values among the group exposed to water arsenic, $>50 \mu \mathrm{g} / \mathrm{L}$. It is also evident that the urinary porphyrins excreted among the group exposed to water arsenic, $<50 \mu \mathrm{g} / \mathrm{L}$ in the arsenic endemic area were higher compared to that of control area in all three different age groups under study indicating alterations in the porphyrin profile even earlier than the appearance of cutaneous manifestations of arsenicosis. The decarboxylation process in the heme-biosynthetic pathway started with uro III by the enzyme, uroporphyrinogen decarboxylase to produce hepta I, hexa I and penta I followed by production of copro III. No regular change in the urinary excretion pattern of hexa I and penta I was noticed between exposed and control population of arsenic endemic area except in few cases. The ratio of copro III to uro III was found to increase with increase in arsenic exposure as well as with age. The rate of increment of the ratio has been noticed to be higher in female compared to male which may be corroborated by higher urinary arsenic of female than male.

Hernandez-Zavala et alalso reported elevated levels of uro III and copro III in urine among population chronically exposed to arsenic via drinking water in Mexico [34]. The uro III reported to be lower compared to that obtained in the present study, whereas the copro III was higher. The copro III/uro III ratio of the present study was found to be lower compared to that reported by Hernandez-Zavala et al [34]. Liu et alreported from the arsenic endemic area of China also showed more or less similar results of porphyrins, uro III and copro III akin to that of the present study [32]. In another study of urinary excretion pattern of porphyrins among population exposed to arsenic in drinking water, Garcia-Vargas et al reported significant reductions in copro III and uro III, resulting decrease in the copro/uro ratio [33]. The author obtained a direct relationship between timeweighted exposure to arsenic and alterations in urinary porphyrin excretion ratios with a lower uroporphyrinogen decarboxylase activity in arsenic exposed individuals. Similar observations were also noted by $\mathrm{Ng}$ et al [12], Wang et al [35] and Xie et al.[43] in their studies of urinary porphyrins among the subjects exposed to arsenic due to coal burning in China and also by Telolahy et al [36] and Apostoli et al [44] in their studies of urinary porphyrins, respectively in smelter workers and art glass workers. The hepta I levels obtained in the present study were found to be lower compared to the two porphyrins, uro III and copro III, in exposed and control population. Present study also reveals that there are distinct alterations in porphyrin ratios (copro III/uro III) between the exposed and control population even among population exposed to water arsenic, $<50 \mu \mathrm{g} / \mathrm{L}$. Thus, alterations in porphyrin ratio may serve as early biomarker of chronic arsenic exposure. Hernandez-Zavala et al reported alteration in heme-metabolism among individuals highly exposed to arsenic, by elevated porphyrin excretions, mainly copro III and uro III which increase the activities of porphobilinogen deaminase (PBG-D) and uroporphyrinnogen decarboxylase (URO-D) enzymes [34]. Therefore, the elevated urinary levels of copro III and uro III, in the present study also reveal alteration in heme-metabolism among arsenic exposed individuals though the severity of the effect depends on potency of exposure. Significant variations of porphyrins (uro III, 
hepta I, and copro III) between exposed and control as obtained in the present study support the hypothesis that arsenic affects the enzyme activities as had been reported by HernandezZavala et. al [34].Compared with control group, the concentration of all the porphyrins generally increases after arsenic exposure but to different degrees with respect to age group, gender and specific porphyrin compounds [35].

This study estimated MDA as a biomarker of oxidative stress and noticed that gradual increment in MDA concentration in urine of exposed population with increase in arsenic content in drinking water as well as with the age in most cases. The MDA levels were also increased among exposed population compared to the control for both, male and female, indicating oxidative stress condition among the exposed population. The higher MDA levels among the female compared to male, especially in the older age group, > 50 years also corroborate higher exposure to arsenic. It has also been noticed that the MDA levels in the arsenic exposed category, $<50 \mu \mathrm{g} / \mathrm{L}$ were higher than the control population, which reveals the fact that the release of MDA starts well before the appearance of skin manifestation (skin pigmentation and keratosis). The external manifestation of skin lesion is expected to be very less in this exposed category. Our findings support that MDA, like porphyrins, may be a sensitive early warning marker of oxidative stress for the population in arsenic endemic area. A larger sample size would have reflected better in the significant tests.

It has been noticed that there was a gradual increase in uro III, hepta I and copro III, the ratio of copro III/uro III and MDA with respect to the arsenic content in urine. A distinct variation in all these parameters was also observed between the population residing in arsenic endemic area and in the control. On the contrary, hexa I and penta I was found to decrease with increased urinary arsenic. Significant alterations in porphyrin profiles as well as its positive correlation with urinary arsenic of exposed population suggest that it can be used as an effective early warning biomarker of arsenic on the heme-biosynthetic pathway. Elevated MDA and its significant variations compared to control corroborate lipid peroxidation causing oxidative stress among the arsenic exposed population.
It has been found that for all the porphyrin parameter significant increase was observed for the subject of age $<30$ years and $>50$ years. It shows that these two groups are mostly affected.

In case of population, exposed to water arsenic, $<50 \mu \mathrm{g} / \mathrm{L}$ in exposed area, changes in porphyrin concentrations i.e uro III, hepta I and copro III occurred but the evidence of skin lesions was not observed. Arsenicosis skin lesions (4.9\%) were observed in population, exposed to water arsenic, $>50 \mu \mathrm{g} / \mathrm{L}$. In the population, exposed to water arsenic, $<50 \mu \mathrm{g} / \mathrm{L}$, changes in porphyrin profile noticed before appearance of skin lesions,. So these porphyrines, i.e uro III, hepta I and copro III can be treated as early biomarkers. Similarly concentration of MDA was higher in population, exposed to water arsenic, $<50 \mu \mathrm{g} / \mathrm{L}$ than from control population, although the later group contain no arsenicosis cases. Similarly, the changes in MDA concentration before appearance of skin lesions may also be treated as early biomarker.

\section{Conclusions}

The present work reveals a positive correlation of urinary porphyrins and MDA among different arsenic exposed categories compared to their respective control indicating bio-chemical toxicity and oxidative cellular damage of the exposed individuals in our current study in arsenic endemic area of West Bengal. This study further demonstrates the alteration in urinary porphyrin excretion, particularly the porphyrin ratio, induced by high arsenic in drinking water as well as below the National Standard among exposed individuals. Alterations of porphyrin profiles like uro III and copro III even in the younger age group support that these may serve as potential early biomarkers. Similar changes as observed in MDA level also confirm its suitability as an indicator of oxidative stress of chronic arsenic exposure. Water intervention programs in these regions of West Bengal need to be implemented without further delay. The parameters, porphyrins and MDA, are really novel indeed as have been reported by the authors at the arsenic endemic area from West Bengal, India.

\section{ACKNOWLEDGEMENTS}

The authors wish to express their sincere thanks to the Officer in charge, Regional Occupational Health Centre (Eastern), Kolkata, Director, National Institute of Occupational Health, Ahmedabad and Indian Council of Medical 
Research, New Delhi for providing all infrastructural support, permission to take the work as Ph.D. programme and to publish the paper. The work was partially supported by the Department of Bio-technology, Government of India.

\section{REFERENCES}

[1] Shankar S., Shanker U., Shikha, Arsenic contamination of Groundwater: A review of sources, prevalence, health risks and strategies for mitigation, The Scientific world Journal. 2014, 1-18 (2014).

[2] GuhaMazumder D.N., Haque R., Ghosh N., De B.K., Santra A. Chakraborty, D., Smith A. H., Arsenic levels in drinking water and the prevalence of skin lesions in West Bengal, India. Int J Epidemiol. 27, 871-877 (1998).

[3] Lien H.C., Tsai, T.F., Lee Y.Y., Hsiao C.H., Merkel cell carcinoma and chronic arsenicism, J Am Acad Dermatol. 41(4), 641-643 (1999).

[4] Mazumder D.N., Das-Gupta J., Santra A., Chronic arsenic toxicity in West Bengal-the worse calamity in the world, J Indian Med Assoc. 96(1), 4-7, 18 (1998).

[5] Lewis D.R., Southwick J.W., Ouellet-Hellstrom R.; Rench J., Calderon, R.L., Drinking water arsenic in Utah: a cohort mortality study, Environmental Health Perspectives. 107(5), 359-365 (1999).

[6] Ratnaike R.N, Review- Acute and chronic arsenic toxicity, Postgrad Med J. 79, 391-396 (2003).

[7] IARC, 2004; World Health Organization, 2001. Some drinking-water disinfectants and contaminants, including arsenic.IARC Monograph on the Evaluation of Carcinogenic Risks to Humans. 2004; 84: 271-441.

[8] Chen Y., Parvez F., Gamble M., Islam T., Ahmed A., Argos M., Graziano J.H., Ahsan H., Arsenic exposure at low-to-moderate levels and skin lesions, arsenic metabolism, neurological functions, and biomarkers for respiratory and cardiovascular diseases: Review of recent findings from the Health Effects of Arsenic Longitudinal Study. (HEALS) in Bangladesh, Toxicology and Applied Pharmacology. 239(2), 184-192(2009).

[9] Hughes M.F., Biomarkers of Exposure: A Case Study with Inorganic Arsenic, Environmental Health Perspectives. 114(11), 17901796(2006).

[10] International Agency for research on cancer, 1987. Arsenic and arsenic compounds. IARC monographs on the evaluation of the carcinogenic risks to humans.23( Supplement 7): 100-103.
[11] U.S.EPA 1993. Arsenic, Inorganic (CASRN 7440-38-2)Integrated Risk Information System (IRIS). Washington, DC: US. Environmental Protection Agency. Available: http://www.epa.gov/iris/subst/0278.htm[31st March, 2005].

[12] Ng J.C., Wang J.P., Zheng B.S., Zhai C., Maddalena, R., Liu, F.; Moore M.R., Urinary porphyrins as biomarkers for arsenic exposure among susceptible populations in Guizhou Province, China, Toxicology And Applied Pharmacology. 206(2), 176-184. (2005)

[13] Marks G.S., Exposure to toxic agents: the heme biosynthetic pathway and hemoproteins as indicator, CRC Crit. Rev.Toxicol. 15, 151179(1985).

[14] Burtis C.A., Bruns D.E., Chapter 29. Tietz Fundamentals of Clinical chemistry and molecular diagnostics., Seventh edition.Elsevier. $\quad$ Copyright: 2015, ISBN:9781455741656.

[15] Gloria F.C., Heme Biosynthesis: Biochemistry, Mollecular Biology and Relationship to Disease. Journal of Bioenergetics and Biomembranes. 27, 147(1995).

[16] Layer G.J., Reichelt D., Jahn D.W., Structure and function of enzymes in heme biosynthesis. Protein Sci. 19(6),1137-1161(2010).

[17] Kern J.K., Geier D.A., Adams J.B., Mehta J.A., Grannemann B.D., Geier M.R., Toxicity biomarkers in autism spectrum disorder: A blinded study of urinary porphyrins, Pediatrics International.53,147-153(2011).

[18] Geier D.A., Pretorius H.T., Richards N.M., Geier M.R., A quantitative evaluation of brain dysfunction and body-burden of toxic metals, Med Sci Monit. 18(7), 425-431 (2012).

[19] Chang L.W., Magos L., Suzuki T., Toxicology of metals. Boca Raton: Lewis Publishers. (1996).

[20] Puy H., Gouya L., Deybach J.C.., Porphyrias. Lancet. 375: 924-37 (2010).

[21] Daniell W.E., Stockbridge H.L., Labbe R.F., Woods J.S., Anderson K.E., Bissell D.M., Bloomer J.R., Ellefson R.D., Moore M.R., Pierach C.A., Schreiber W.E., Tefferi A., Franklin G.M., Environmental chemical exposures and disturbances of heme synthesis, Environ Health Perspect. 105, 37-53 (1997).

[22] Harada K., Ohmori S., Kim Y., Tomokuni K., Metabolic fate of porphyrin and its precursors in porphyria and porphyrinuria, Nihon Rinsho. 53,1349-56 (1995).

[23] Marks G.S.,Zelt D.T., Cole S.P., Alterations in the heme biosynthetic pathway as an index of exposure to toxins, Can J PhysiolPharmacol. 60(7),1017-1026 (1982).

[24] Jomova K., Jenisova Z., Feszterova M., Baros S., Liska,J., Hudecova D., Rhodes C.J., Valko 
M., Arsenic: toxicity, oxidative stress and human disease, J. Appl. Toxicol. 31, 95-107 (2011).

[25] Pi J., Yamauchi H., Kumagai Y., Sun G., Yoshida T., Aikawa H., Hopenhayn-Rich C., Shimojo N., Evidence for induction of oxidative stress caused by chronic exposure of Chinese residents to arsenic contained in drinking water, Environ Health Perspect. 2002; 110(4): 331-6.

[26] Del Rio D., Stewart A.J., Pellegrini N., A review of recent studies on malondialdehyde as toxic molecule and biological marker of oxidative stress, Nutr Metab Cardiovasc Dis. 15(4), 316-328 (2005).

[27] Davey M.W., Stals E., Panis B., Keulemans J., Swennen R.L., "High-throughput determination of malondialdehyde in plant tissues", Analytical Biochemistry. 347(2): 201-207 (2005).

[28] Pryor W.A., Stanley J.P., "Letter: A suggested mechanism for the production of malondialdehyde during the autoxidation of polyunsaturated fatty acids. Nonenzymatic production of prostaglandin endoperoxides during autoxidation", J. Org. Chem. 40(24), 3615-3617 (1975).

[29] Moore K., Roberts L.J., "Measurement of lipid peroxidation", Free Radic. Res. 28(6), 659-671 (1998).

[30] Shi H., Shi X., Liu K.J., Oxidative mechanism of arsenic toxicity and carcinogenesis, Mol. Cell. Biochem. 255, 67-78 (2004).

[31] Wang J.P., Maddalena R., Zheng B., Zai C., Liu F., Ng J.C., Arsenicosis status and urinary malondialdehyde (MDA) in people exposed to arsenic contaminated-coal in China, Environment International. 35(3), 502-506 (2009).

[32] Liu F.F., Wang J.P., Zheng Y.J., Ng J.C., Biomarkers for the evaluation of population health status 16 years after the intervention of arsenic-contaminated groundwater in Xinjiang, China, Journal of Hazardous Materials. 262, 1159-1166 (2013).

[33] Garcia-Vargas G.G., Del Razo L.M., Cebrian M.E., Albores, A., Ostrosky-Wegman P., Montero R., Gonsebatt M.E. Lim C.K. De Matteis F., Altered Urinary Porphyrin excretion in a human population chronically exposed to arsenic in Mexico, Human \& Experimental Toxicology. 13, 839-847 (1994).HernandezZavala A., Del Razo L.M., Garcia-Vargas G.G., Aguilar C., Borja V.H., Arnulfo A. Cebrian
M.E., Altered activity of heme biosynthesis pathway enzymes in individuals chronically exposed to arsenic in Mexico, Archives of Toxicology. 73, 90-95 (1999).

[34] Wang J.P., Qi L., Zheng B., Liu F., Moore M.R., Ng J.C., Porphyrins as early biomarkers for arsenic exposure in animals and humans, Cellular And Molecular Biology. 48(8), 835843 (2002).

[35] Telolahy P., Javelaud B., Cluet J., de Ceaurriz $\mathrm{J}_{.,}$, Boudene $\mathrm{C}_{.,}$Urinary excretion of porphyrins by smelter workers chronically exposed to arsenic dust, Toxicol Lett. 66 (1), 89-95 (1993).

[36] Chatterjee A., Das D., Mandal D.K., Chowdhuri T.R., Samanta G., Chakraborty D., Arsenic in ground water in six district of West Bengal: the biggest arsenic calamity in the world, Part I- Arsenic species in drinking water and urine of the affected people, Analyst. 120, 643-650 (1995).

[37] Das D., Chatterjee A., Mandal B.K., Samanta G., Chakraborti D., Arsenic in ground water in six districts of West Bengal, India: the biggest arsenic calamity in the world, Part II. Arsenic concentration in drinking water, hair, nails, urine, skin-scale and liver tissue (biopsy) of the affected people, Analyst. 120, 917-924 (1995).

[38] Lee K.H., Kang D., Stability and IntraIndividual Variation of Urinary Malondialdehyde and 2-Naphthol, Korean J Prev Med. 41(3), 195-199 (2008).

[39] Chatterjee A., Das D., Chakraborty D., A study of ground water contaminated by arsenic in the residential area of Behala, Calcutta due to Industrial Pollution, Environmental Pollution. 80, 57-65 (1993).

[40] Peters, J.H., The determination of creatinine and creatine in blood and urine with photoelectric colorimeter, Journal of Biological Chemistry. 146, 179-186 (1942).

[41] Mazumder D.N.G., Clinical Aspect of Chronic Arsenic Toxicity. JAPI. 49, 650-655 (2001).

[42] Xie Y., Kondo M., Koga H., Miyamoto H., Chiba M., Urinary porphyrins in patients with endemic chronic arsenic poisoning caused by burning coal in China, Environmental Health and Preventive Medicine. 5, 180-185 (2001).

[43] Apostoli P., Sarnico M., Bavazzano P., Bartoli D., Arsenic and porphyrins, American Journal of Industrial Medicine. 42, 180-187 (2002).

Citation: Ashit K. Mukherjee, Sujoy K. Manna, Sanjit K. Roy \& Jnan P. Naskar. Urinary Porphyrin Profile as Early Biomarker vis-a-vis Malonaldehyde as Oxidative Stress Indicator in Arsenic Exposed Individuals, West Bengal, India. ARC Journal of Public Health and Community Medicine.2017; 2(3):37-52: dx.doi.org/10.20431/2456-0596.0203008

Copyright: (C) 2017 Authors. This is an open-access article distributed under the terms of the Creative Commons Attribution License, which permits unrestricted use, distribution, and reproduction in any medium, provided the original author and source are credited. 